УДК 616.24-007.227: 616. 131-008. 331. 1:616.12-008.331.1-085

DOI 10.11603/24116-4944.2017.1.7581

๑С. Б. Чечуга, М. А. Войцешина

Віннищький національний медичний університет ілені М. І. Пирогова

\title{
ТАКТИКА ВЕДЕННЯ ТА РОЗРОДЖЕННЯ ЖІНОК ІЗ РЕЗУС-КОНФЛІКТНОЮ ВАГІТНICTЮ
}

Мета дослідження - знизити перинатальну захворюваність і смертність у жінок із резус-конфліктною вагітністю шляхом оптимізації підходів до її ведення та тактики розродження.

Матеріали та методи. Проведено ретроспективний аналіз 68 історій пологів та індивідуальних карток жінок із резусконфрліктною вагітністю та проспективне обстеження 43 жінок із резус-конфлліктною вагітністю, які склали основну групу. Контрольну групу склали 34 жінки із резус-негативною групою крові без титру антитіл. Дослідження проводили на базі міської лікарні «Центр матері та дитини» м. Вінниці.

Результати дослідження та їх обговорення. У роботі проведена оцінка діагностичної цінності пікової систолічної швидкості кровотоку в середній мозковій артерії плода в поєднанні з показниками біофрізичного профілю та STV-тесту як діагностичного критерію стану плода при резус-конфрліктній вагітності. В результаті проведеного дослідження визначений та апробований новий підхід до пренатальної діагностики важкості стану плода при резус-коноліктній вагітності, розроблений алгоритм її комплексного ведення та показань до розродження.

Висновок. Запропонований ефективний та патогенетично обумовлений алгоритм ведення резус-конфліктної вагітності з визначенням пікової систолічної швидкості кровотоку в середній мозковій артерії як діагностичного критерію стану плода дозволяє зменшити кількість інвазивних процедур, частина яких супроводжується втратою вагітності, і значно поліпшити перинатальні наслідки.

Ключові слова: вагітність; резус-конфлікт; гемолітична хвороба новонародженого; швидкість кровотоку в середній мозковій артерії плода.

\section{ТАКТИКА ВЕДЕНИЯ И РОДОРАЗРЕШЕНИЯ ЖЕНЩИН С РЕЗУС-КОНФЛИКТНОЙ БЕРЕМЕННОСТЬЮ}

Цель исследования - снизить перинатальную заболеваемость и смертность у женщин с резус-конфрликтной беременностью путем оптимизации подходов к ее ведению и тактики родоразрешения.

Материалы и методы. Проведено ретроспективный анализ 68 историй родов и индивидуальных карточек женщин с резус-конфрликтной беременностью и проспективное обследование 43 женщин с резус-конорликтной беременностью, которые составили основную группу. Контрольную группу составили 34 женщины с резус-отрицательной группой крови без титра антител. Исследование проводили на базе городской больницы «Центр матери и ребенка» г. Винницы.

Результаты исследования и их обсуждение. В работе проведена оценка диагностической ценности пиковой систолической скорости кровотока в средней мозговой артерии плода в сочетании с показателями биофизического профиля и STV-теста как диагностического критерия состояния плода при резус-коноликтной беременности. В результате проведенного исследования определен и апробирован новый подход к пренатальной диагностике тяжести состояния плода при резус-консрликтной беременности, разработанный алгоритм ее комплексного ведения и показаний к родоразрешению.

Вывод. Предложенный эффективный и патогенетически обусловленный алгоритм ведения резус-конфрликтной беременности с определением пиковой систолической скорости кровотока в средней мозговой артерии в качестве диагностического критерия состояния плода позволяет уменьшить количество инвазивных процедур, часть которых сопровождается потерей беременности, и значительно улучшить перинатальные исходы.

Ключевые слова: беременность; резус-консрликт; гемолитическая болезнь новорожденного; скорость кровотока в средней мозговой артерии плода.

\section{MANAGEMENT TACTICS AND DELIVERY OF WOMEN WITH RH-CONFLICT PREGNANCY}

The aim of the study - to reduce perinatal morbidity and mortality in women with Rh-conflict pregnancy by optimizing approaches to its maintenance and tactics delivery.

Materials and Methods. We conducted retrospective analysis of 68 birth stories and individual cards of women with Rh-conflict pregnancy and prospective survey of 43 women with Rh-conflict pregnancy, which formed the main group. The control group consisted of 34 women with Rh-negative blood group without antibody titer. The study was conducted at the Maternity Hospital «Center of Mother and Child» in Vinnytsia.

Results and Discussion. We evaluated the diagnostic value of peak systolic flow velocity in the middle cerebral artery of the fetus in combination with biophysical indicators and STV - test as a diagnostic test of the fetus with Rh-conflict pregnancy. The study identified and tested a new approach to prenatal diagnosis of the severity of fetal Rhesus conflict with the pregnancy, the algorithm of treatment and indications for delivery.

Conclusions. An efficient algorithm and pathogenetically caused by driving Rh-conflict pregnancy definition of peak systolic flow velocity in the middle cerebral artery as a diagnostic test of the fetus can reduce the number of invasive procedures, some of which are accompanied by a loss of pregnancy, and significantly improve perinatal outcomes.

Key words: pregnancy; rhesus-conflict; hemolytic disease of newborn; blood flow velocity in the middle cerebral artery of fetus. 
ВСтуп. Резус-конфрліктна вагітність є актуальною проблемою сучасного акушерства та неонатології. В 5-6 \% випадків гемолітична хвороба новонароджених (ГХН) є причиною антенатальної загибелі плода і в 5-9 \% призводить до загибелі новонароджених у ранньому неонатальному періоді. Важливим фрактором, який сприяє зростанню перинатальних втрат за даної патології, $€$ високий рівень народження вкрай незрілих дітей. Причиною цього $є$ розродження на ранніх термінах у випадку загрози для життя плода $[1-3,5]$.

Діагностика ГХН довгий час була основана тільки на анамнестичних даних і оцінці сумарного титру антитіл [3, 5]. В останні десятиліття після впровадження в широку лікарську практику ультразвукової діагностики з'явилась можливість верифікувати спочатку набрякову фрорму ГХП, а потім - інші форми захворювання [8]. Проте, як показали подальші дослідження, подібна діагностика виявилась недосконалою, оскільки не дозволяла у всіх випадках виявити анемічний синдром у плода, що є причиною розвитку у нього набряку. Дотепер об'єктивним і достовірним методом діагностики анемічного синдрому у плода залишався кордоцентез [8]. Ще однією діагностичною процедурою, що довгий час вважалась основною в алгоритмі діагностики ГХП, був амніоцентез. Але це $є$ інвазивні діагностичні процедури, що можуть супроводжуватися ризиком розвитку акушерських ускладнень. За даними ряду авторів, непрямим показником наявності анемії у плода може бути збільшення швидкості кровотоку в артеріях плода, що визначена за допомогою доплерометрії з використанням кольорового доплерівського картування [9]. Вперше метод визначення МСШ кровотоку в СМА плода був запропонований для діагностики важкості гемолітичної хвороби плода G. Mari et al. [9]. Зміна швидкості кровотоку в середній мозковій артерії плода відбувається дуже швидко у відповідь на гіпоксемію, що $є$ показником адаптивної реакції перерозподілу кровотоку у плода при зниженні рівня кисню в його крові. G. Mari et al. [10] запропонували представляти отримані абсолютні величини кровотоку у вигляді МоМ, що відображало їх відхилення від медіани для відповідного терміну вагітності. Вони виявили, що анемія у плодів виявлялась значно частіше при показниках швидкості кровотоку в СМА, що перевищували 1,5 МоМ. А плоди, у яких значення МСШ були нижче 1,5 МоМ, або мали анемію легку, або не мали ії̈ взагалі [10].

МЕТА ДОСЛІДЖЕННЯ - ЗНизити перинатальну захворюваність і смертність у жінок із резус-конфрліктною вагітністю шляхом оптимізації підходів до ії̈ ведення та тактики розродження.

МАТЕРІАЛИ ТА МЕТОДИ. Для вирішення поставлених завдань і мети першим етапом дослідження стало проведення ретроспективного аналізу 68 історій пологів та індивідуальних карток жінок із резус-конфрліктною вагітністю. Дослідження проводили на базі міської лікарні «Центр матері та дитини» М. Вінниці за 2014-2015 роки. Другим етапом нашого дослідження було проспективне обстеження 43 жінок із резус-конфрліктною вагітністю, які склали основну групу. Клінічним критерієм включення жінок до основної групи проспективного дослідження була резус-негативна група крові у жінок з наявністю титру антитіл із резус-позитивними чоловіками. Контрольну групу склали 34 жінки 3 резус-негативною групою крові без титру антитіл із резус-позитивними чоловіками. Дослідження проводили на базі міської лікарні «Центр матері та дитини» м. Вінниці за 2015-2016 роки. Всім вагітним визначали рівень титру резус-антитіл, до 30 тижнів - 1 раз на місяць, після 30 тижнів - кожні 2 тижні, при різкій зміні рівня титру антитіл динаміку відслідковували кожні 3-5 днів. Всім досліджуваним групам проводили ультразвукове та доплерометричне дослідження з використанням ультразвукового апарата GE Voluson E8, що обладнаний доплерівським блоком. Біометрію плода проводили за стандартною методикою з обов'язковим вимірюванням розмірів печінки плода, товщини плаценти та кількості навколоплідних вод. Доплерометричне дослідження проводили в судинах пуповини, венозній протоці та середній мозковій артерії за стандартною методикою. При оцінці швидкості кровотоку в СМА плода конвертування отриманих результатів в МоМ проводили у спеціальній програмі на сайті http://www.perinatology.com/calculators/ MCA.htm або http://medicinafetalbarcelona.org/calc/.

Також проводили оцінку біофрізичного профілю плода та, 328 тижнів, КТГ +stv test плода за допомогою монітора Sonic-Aid.

РЕЗУЛЬТАТИ ДОСЛІДЖЕННЯ ТА ЇХ ОБГОВОРЕННЯ. При ретроспективному аналізі 68 історій пологів та індивідуальних карт вагітних та породіль було виявлено, що вихідний рівень титру антитіл складав 1:4-1:16. Тактика ведення даних жінок була відповідно до наказів МО3 України № 417 та № 676. Було виявлено, що у 59 жінок $(86,7$ \%) відмічалось наростання рівня титру антитіл під час вагітності до 1:64 - 1:512. У 50 жінок (84,7 \%) з них, не зважаючи на задовільний стан плода відповідно до БПП, КТГ, доплерометрії, відсутність ознак ГХП та зважаючи на термін гестації (34 тижні та більше), було проведено розродження відповідно до акушерської ситуації. 19 жінок (38 \%) народили шляхом операції кесарського розтину, 31 жінка (62 \%) - через природні пологові шляхи. У всіх випадках оцінка за шкалою Апгар на першій хвилині життя склала у середньому 6-7 балів. У 9 дітей (18 \%) розвинулася гемолітична хвороба новонароджених, жовтянична форма, легкий перебіг. Діагнози були підтверджені лабораторним визначенням гемоглобіну, гематокриту, білірубіну пуповинної крові та в динаміці. У 9 жінок 3 групи ретроспективного дослідження (13,3 \%) були наявні УЗД-ознаки гемолітичної хвороби плода, такі, як: багатоводдя, гепатомегалія, спленомегалія, асцит та подвійний контур голівки. Титри антитіл у цих жінок були 1:16 - 1:512. Ці жінки були розроджені терміново шляхом операції кесарського розтину, враховуючи термін вагітності (30-36 тижнів) та неготовність пологових шляхів. У 8 випадках (88 \%) оцінка за шкалою Апгар на першій хвилині життя була 4-6 балів, на п'ятій - 5-7 балів. А в стані важкої асфріксії з оцінкою за Апгар 2 бали на першій хвилині життя народилася 1 дитина (32 тижні вагітності), що мала набрякову фрорму гемолітичної хвороби, важкий перебіг, та померла на 2 добу життя. У даному випадку титр антитіл був 1:32. Отже, отримані нами дані дозволяють говорити про те, що абсолютні значення рівня резус-антитіл не можуть слугувати достовірним критерієм важкості гемолітичної хвороби плода, а у більшості випадків лише відображають ступінь імунізації вагітної. В основній групі проспективного дослідження підхід до ведення вагітності був дещо зміненим. Окрім оцінки 
рівня антитіл та УЗ-сретометрії, важливим діагностично цінним показником стало вимірювання швидкості кровотоку в СМА плода, а саме оцінка цієї швидкості в МоМ, що свідчить про анемію у плода. Було досліджено, що у 38 жінок (88,3 \%) основної групи відмічалося збільшення швидкості кровотоку в СМА > 1,5 МоМ, що було розцінено як наявність анемії у плода, та, залежно від терміну гестації та акушерської ситуації, проведено розродження вагітних. У 30 випадках (79 \%) була проведена індукція пологів, враховуючи термін гестації та готовність пологових шляхів. 3 них 25 жінок (83\%) народили через природні пологові шляхи, 5 (17\%) - шляхом операції кесарського розтину внаслідок дистресу плода в пологах чи неефективності індукції пологів. У 8 випадках (21 \%) пологи відбулись шляхом операції кесарського розтину. 3 них у 6 випадках (75 \%) це були передчасні пологи у терміні гестації 32-36 тижнів. I у 2 випадках (25\%) через неготовність пологових шляхів при доношеній вагітності. У 35 випадках оцінка за шкалою Апгар на першій хвилині становила 7-8 балів. В стані легкої ассріксії (оцінка за Апгар 5-6 балів на першій хвилині життя) народилося 3 дитини. У всіх цих дітей була підтверджена гемолітична хвороба новонароджених, жовтянична фрорма, легкий перебіг. Діагнози були підтверджені лабораторним визначенням гемоглобіну, гематокриту, білірубіну пуповинної крові та в динаміці. У 5 жінок основної групи протягом вагітності не 3'явилося жодних ознак гемолітичної хвороби у плода та не було підвищення швидкості кровотоку в СМА плода, тому вони були розроджені в терміні 37 тижнів. У жодної 3 жінок групи контролю не було виявлено жодних ознак розвитку гемолітичної хвороби плода, тому їх розродження відбувалось залежно від акушерської ситуації. Лише у декількох випадках було діагностовано багатоводдя, але це не було розцінено як початок розвитку гемолітичної хвороби плода. Підвищення швидкості кровотоку в СМА у плодів даної групи пацієнток, за даними доплерометрії, було відсутнє, і, відповідно, лабораторні показники крові новонароджених відповідали фрізіологічним показникам. Отже, проведене нами дослідження дозволило виявити, що найбільшою інформативністю для діагностики анемії плода володіє збільшення максимальної систолічної швидкості кровотоку в середній мозковій артерії плода.

ВИсновкИ. Аналіз показав, що метод визначення швидкості кровотоку в СМА плода $є$ високочутливим і специфрічним для виявлення анемії у плода і може слугувати неінвазивним індикатором терміну розродження. Спираючись на цей метод, можна пролонгувати вагітність до життєздатного віку плода, не зважаючи на рівні титру резус-антитіл та без проведення інвазивних втручань. Але, незважаючи на загальні підходи до ведення даного контингенту жінок, кожен випадок потребує індивідуального підходу до діагностики та лікування.

ПЕРСПЕКТИВИ ПОДАЛЬШИХ ДОСЛІДЖЕНЬ ПОлягають у визначенні оптимальних показників швидкості кровотоку в середній мозковій артерії плода для термінового розродження.

\section{СПИСОК ЛІТЕРАТУРИ}

1. Ошовський В. І. Акушерські аспекти резус-конорліктної вагітності: діагностика, лікування, шляхи профілактики : методичні рекомендації / В. І. Ошовський, І. О. Ошовська. - К., 2013.

2. Акушерство. Справочник Калифорнийского университета / под ред. К. Нисвандера, А. Эванса ; пер. с англ. - М. Практика, 1999. - 704 с.

3. Васильева 3. Ф. Иммунологические основы акушерской патологии / 3. Ф. Васильева, В.Н.Шабалин. - М. : Медицина, 1984. - 192 с.

4. Основы перинатологии / ред. Н. П. Шабалов, Ю. В. Цвелев. - М. : МЕДпресс-инорорм, 2004. - 640 с.

5. Персианинов Л. С. Гемолитическая болезнь плода и новорожденного / Л. С. Персианинов, В. М. Сидельникова, И. П. Елизарова. - М. : Медицина, 1981. - 208 с.

6. СадыковГ. Ф.Гемолитическаяболезньуноворожденных/ Г. Ф. Садыков, Д. П. Игнатьева. - Казань, 1988.

\section{REFERENCES}

1. Oshovskyi, V.I. \& Oshovska I.O. (2013). Akusherski aspekty rezus-konfliktnoi vahitnosti: diahnostyka, likuvannia, shliakhy profilaktyky. [Obstetric aspects of Rh-conflict pregnancy: diagnosis, treatment and ways of prevention.]. Kyiv [in Ukrainian].

2. Nysvander, K. \& Evans, A. (Eds.). (1999). Akusherstvo. Spravochnik Kalifornyiskogo Universiteta [Obstetrics. Directory of the University of California]. Moscow [in Russian].

3. Vasyleva, Z.F. \& Shabalyn, V.N. (1984). Immunologicheskie osnovy akusherskoy patologii. [Immunological basis of obstetrical pathology]. Moscow: Meditsina [in Russian].

7. Харман К. Роль эхографии при ведении беременных с иммунопатологией / К. Харман // Эхографрия в акушерстве и гинекологии. Теория и практика : в II частях. Ч. II / ред. А. Фишер; пер. с англ. -6-е изд. - М. : Изд. дом Видар, 2004.

8. Nicolaides K. N. Failure of ultrasonographic parameters to predict the severity of fetal anemia in rhesus isoimmunization / K. H. Nicolaides // Am. J. Obstet. Gynecol. - 1988. - Vol. 158, № 4. - P. 920-926.

9. Mari G. Fetal middle cerebral artery maximal Systolic velocity and pulsality index as indicators of fetal anemia / G. Mari // Scientific program and abstracts of 37th Annual Meeting of the Society, for Gynecologic Investigation. - St. Louis, 1990. - P. 253.

10. Mari G. Noninvasive diagnosis by Doppler ultrasonography of fetal anemia due to maternal red-cell alloimmunization $/$ G. Mari // N. Engl. J. Med. - 2000. - Vol. 342, № 1. - P. 9-14. 
7. Harman, K. (Eds.) (2004). Rol egografii pri vedenii beremennyh $\mathrm{s}$ immunopatologiey. [The role of echography in the management of pregnant women with immunopathology] Ehografiya $v$ akusherstve i ginekologii. Teoriya i praktika. [Echography in obstetrics and gynecology. Theory and practice]. (Trans.). (6 $6^{\text {th }}$ ed.). Moscow: Vidar [in Russian].

8. Nicolaides, K.H. (1988). Failure of ultrasonographic parameters to predict the severity of fetal anemia in rhesus isoimmunization. American Journal of Obstetrics and Gynecology, 158, 4, 920-926.

9. Mari, G. (1990). Fetal middle cerebral artery maximal Systolic velocity and pulsality index as indicators of fetal anemia. Scientific program and abstracts of 37th Annual Meeting of the Society, for Gynecologic Investigation, 253. St. Louis.

10. Mari, G. (2000). Noninvasive diagnosis by Doppler ultrasongraphy of fetal anemia due to maternal red-cell alloimmunization. New England Journal of Medicine, 342, 1, 9-14. 